\title{
COMPARING ROLE PLAYING MODEL AND GROUP GUIDANCE TO IMPROVE STUDENTS' ENTREPRENEURSHIP SKILLS
}

\author{
Shendy Andrie Wijaya1, Muhammad Basri Fanani² \\ IKIP PGRI JEMBER \\ E-mail: shendyandriewijaya@gmail.com
}

Received: February 10, 2019 Accepted: April 7, 2019 Published: July 4, 2019

\begin{abstract}
This study compares the effectiveness of learning model use role playing and group guidance in improving entrepreneurial skills. This study applied true experimental design with postest-only control design model and pretest-postest control group design. The study was conducted on undergraduate students in FPIPS IKIP PGRI Jember as an experimental class with undergraduate students of economic pedagogy in FKIP University Jember as a control class. The finding showed that the role-playing games learning are more effective model instead of group counseling-based learning to improve students' entrepreneurial skills and spirits. For this findings, it is suggested to the lecturer of this course to not only provides theoretical basis but also required to portray the entrepreneurial spirit.
\end{abstract}

Keywords: Role Playing, group guidance, Skills Entrepreneurship

Skills are a must-have capability for everyone, using common sense, mind, idea, and creativity in working, transforming or creating things more useful in order to make the value as the results of the work. Suprapto (2009) argued that skill is an ability to translate knowledge into practice so that the targeted work is achieved. Usman (2009) found that skill is the character, knowledge and personal ability of a person who is relevant in carrying out his duties effectively. The definition illustrates that skills are the character, knowledge, and ability that a person has to be effective and fit his work. Chang and Rieple (2013), (Din et al., 2016) suggested that there are four dimensions of entrepreneurial skills, namely Technical Skills, Management Skills, Entrepreneurship Skills, and Personal maturity skills. Fitriati and Hermiati (2010), (Christina et al., 2015) stated that the process of entrepreneurship includes behaviors, skills, and attributes belonging to a person in entrepreneurial education. Entrepreneurship processes include the behaviors, skills, and attributes that a person has in entrepreneurship education. In order to develop entrepreneurial behavior (Cai et al., 2018), it takes a process that includes identifying the traits associated with entrepreneurship. Both in the form of skills and attributes inherent in entrepreneurship.

This will be applied to the undergraduate students of Economics Pedagogy in IKIP PGRI Jember to access the entrepreneurship course to be able to explore their knowledge while following the entrepreneurial learning practically to hone and improve their entrepreneurial skills, e.g. they can be an entrepreneur as they graduate. Based on the results of initial observation conducted by researchers, so far the learning process activities in entrepreneurship courses are still more 
dominated by the transfer of knowledge between lecturers and students, so the learning achievements are not optimal and students' output that relates to entrepreneurial skills after taking the course is still low, because students after taking entrepreneurship courses are only able to remember and understand the theory learned. Another reason why these entrepreneurial learning objectives need several improvements, it is because in accordance with the purpose of the KKNI curriculum on entrepreneurship courses in higher education, explains that in entrepreneurial learning practices, students required to be able to hone his skills skills in the role of becoming an entrepreneur, the explanation is also supported by Presidential Regulation No. 6 of 2009, about entrepreneurial learning states that, Ministry of Education and Culture through the Directorate General of Secondary Education and the Directorate General of Higher Education have implemented entrepreneurial pedagogy as one of the tangible manifestations to foster a creative, innovative, sportive and entrepreneurship in education methodology as the description of creative economic development. To support the success of these objectives, as well as overcome the problem with the lack of student entrepreneurship skills, then one of them is through the utilization of an effective learning model according to entrepreneurship learning objectives in colleges (Cosenz and Noto, 2018).

One of the learning models is the use of role-playing learning models in each of the submissions of entrepreneurial subject matter. Because in the implementation of the role-playing learning model, students are required to develop their imagination skills and internalize each role performed by the students according to the lesson material (Jones and Pitelis, 2015). The use of role-playing learning models aims to help develop imagination and understanding as well as improve skills by simply playing roles. The role-play starts from the actors and figures according to the material and the problem (Dyson et al., 2016). Thus, students will be interested, happy, and excited because they can learn while playing. In addition, Santoso (2011) said that the role-playing learning model is a way of mastering the materials through the development of students' imagination and the understanding in which there are rules, objectives, and pleasure elements in the teaching and learning process.

It is also shown through the results of the Astuti's (2013) research related to the effectiveness of role-playing methods to improve the communication skills for children, showing the results that the role-playing model was more effective to improve communication skills for children. Students given the treatment of roleplaying methods had a higher communication skills score compared to children who were not given a role-playing learning model. Next, Siska's (2011) research entitled The implementation of role-playing methods in improving social skills and speaking skills of early childhood. The results of this study indicate that there were improvements in second cycle and third cycle to social skills and speaking skills of early childhood through the adoption of role-playing methods. According to Bender's (2005) research entitled Role-playing in online education: A teaching tool to enhance student engagement and sustained learning, the aim of the study provides an opportunity for students to create and participate in role-playing scenarios, instructors can acquire a better knowledge of each student, and students can benefit through improved interactions with the material and one another. The 
result of the research that role-playing learning as an online learning tool can increase student engagement and sustainable learning.

Based on previous problems and research stated, the focus of this study is to use role-playing models to improve student entrepreneurship skills in entrepreneurial learning. Meanwhile, the purpose of this study is to find out first, the effectiveness of the use of role-playing learning models to improve students' entrepreneurial skills. Second, this study intended to examine the effectiveness of the role-playing learning model in entrepreneurial learning outcomes and how they compared to the group guidance model.

\section{METHOD}

This study used True Experimental Design with Postest-Only Control Design model and Pretest-Postest Control Group Design. The study was conducted on undergraduate students of economic pedagogy in FPIPS IKIP PGRI Jember as an experimental class with undergraduate students of economic pedagogy in FKIP University Jember as a control class. The samples used for the experiment as well as the control group were taken randomly from a specific population. The research model is as shown in Table 1.

Table 1 Pretest-Postest Control Group Design Model on Entrepreneurial Learning Outcomes Variables

\begin{tabular}{|c|c|c|c|}
\hline Class & Pre-test & Treatment & $\begin{array}{c}\text { Post- } \\
\text { test }\end{array}$ \\
\hline $\begin{array}{c}\text { KE } \\
\text { (PE IKIP) }\end{array}$ & $\mathrm{O}_{1}$ & $\begin{array}{l}\text { Implementation by using role-playing } \\
\text { learning model }\end{array}$ & $\mathrm{O}_{2}$ \\
\hline $\begin{array}{c}\text { KK } \\
\text { (PE UNEJ) }\end{array}$ & $\mathrm{O}_{3}$ & $\begin{array}{l}\text { Implementation without using role-playing } \\
\text { learning model-group guidance }\end{array}$ & $\mathrm{O}_{4}$ \\
\hline
\end{tabular}

Source: Arikunto (2006)

Description:

KE : Experimental Class (PE IKIP)

KK : Experimental Class (PE UNEJ)

$\mathrm{O}_{1} \quad$ : Early class ability

Experiment

$\mathrm{O}_{2} \quad$ : Early class ability

Experiment

$\mathrm{O}_{3} \quad$ : Initial control class capabilities

$\mathrm{O}_{4} \quad$ : Final control class capabilities

To determine the difference result from experimental research, questionnaire and test were used. The questionnaire uses the Semantic Differential Technique. To interpret the entrepreneurial skills data from the results of the study, the obtained score data is converted into a five-category score using the score conversion guidelines as follows: 
Table 2 Guidelines for Entrepreneurial Skills Scoring Conversion

\begin{tabular}{clc}
\hline Score & \multicolumn{1}{c}{ Conversion Formulas } & Category \\
\hline 5 & $\mathrm{X} \geq \mathrm{Mi}+1.8(\mathrm{SDi})$ & Very good \\
4 & $\mathrm{Mi}+0.6(\mathrm{SDi}) \leq \mathrm{X}<\mathrm{Mi}+1.8(\mathrm{SDi})$ & High \\
3 & $\mathrm{Mi}-0.6(\mathrm{SDi}) \leq \mathrm{X}<\mathrm{Mi}+0.6(\mathrm{SDi})$ & Average \\
2 & $\mathrm{Mi}-1.8(\mathrm{SDi}) \leq \mathrm{X}<\mathrm{Mi}-0.6(\mathrm{SDi})$ & Low \\
1 & $\mathrm{X}<\mathrm{Mi}-1.8(\mathrm{SDi})$ & Very low \\
\hline
\end{tabular}

Source: Azwar (2003)

Description:

$\mathrm{X}=$ total scores

SDi = Ideal standard deviation

$=1 / 6$ (Ideal maximum score - ideal minimum score)

$\mathrm{Mi} \quad=$ Ideal Mean

$=1 / 2($ Ideal maximum score - ideal minimum score $)$

While interpreting the entrepreneurial learning outcome data from the research results, the score data obtained was converted into five categories using the score categorization guidelines as follows:

Tabel 3. Guidelines for Entrepreneurship Learning Outcomes score Category

\begin{tabular}{cc}
\hline Value Range & Category \\
\hline $81-100$ & Very \\
$61-80$ & High \\
$41-60$ & Average \\
$21-40$ & Low \\
$0-20$ & Very low \\
\hline
\end{tabular}

Source: Riduwan (2007)

Before data analysis, a classical assumption test was conducted, then the hypothesized test was used Independent Samples T-Test by SPSS version 20 for Windows. Research hypotheses are:

1. Role-playing learning is more effective than group guidance-based learning to improve students' entrepreneurial skills.

2. Role-playing learning is more effective than group guidance-based learning in entrepreneurial learning.

\section{RESULTS \& DISCUSSION \\ Results}

\section{Descriptive Entrepreneurial Skills Assessment Experiment Class (Y1)}

The respondents' assessment based on each indicator of entrepreneurial skills in the experimental class is presented in the table below:

Table 4 Descriptive Analysis of Entrepreneurial Skills for Experimental Class Statistics Entrepreneurial Skills 


\begin{tabular}{lc}
\hline Mean & 121.57 \\
Variance & 48.723 \\
Highest Value & 137 \\
Lowest Value & 106 \\
Standard Deviation & 6.980 \\
\hline
\end{tabular}

According to table 4, the results of descriptive analysis of the respondent's assessment data on entrepreneurial skills in the experimental class, it can be seen that for the entire indicator items of entrepreneurial skills variable has an average answer value of 121.57, which means very high. Following the results, it can be concluded that the entrepreneurial skills of experimental classes have been improved than before.

\section{Descriptive Assessment of Entrepreneurial Skills in Control Class (Y1)}

The respondents' assessment based on each variable indicator of entrepreneurial skills in the control class is presented in table 5,

\begin{tabular}{lc} 
Table 5 Descriptive Analysis of Entrepreneurial Skills for Control Class \\
\hline \multicolumn{1}{c}{ Statistics } & Entrepreneurial Skills \\
\hline Total respondents & 35 \\
Mean & 116.09 \\
Variance & 41.375 \\
Highest Value & 134 \\
Lowest Value & 104 \\
Standard Deviation & 6.432 \\
\hline
\end{tabular}

According to table 5, the results of entrepreneurial skills in control class are shown, it can be seen that for the entire indicator items of entrepreneurial skills variable has an average answer value of 116.09, which means high. Following with these results, it can be concluded that the entrepreneurial skills of the control classes have improved than before.

\section{Descriptive Entrepreneurial Skills Experimental Class and Control Class}

Comparative assessment of respondents based on each indicator of entrepreneurial skills variable in the experimental class and the control class is presented in Figure 1.

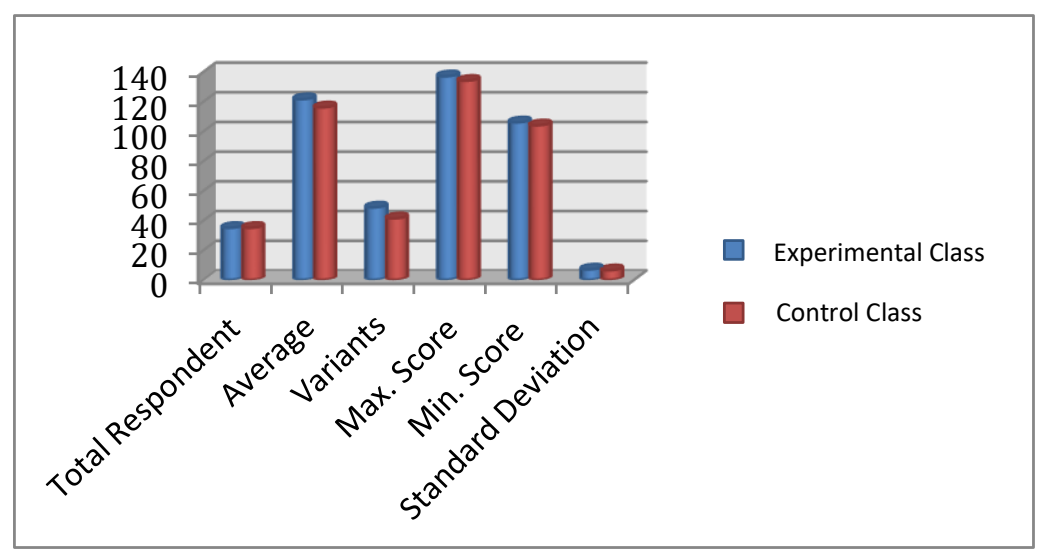




Figure 1 Results of the Recapitulation of
Entrepreneurship Skills Data for the
Experimental Class and the Control Class

Based on Figure 1, from the descriptive analysis of respondent's assessment data to the entrepreneurial skills of the experimental class and control class, it can be noted that for the entire indicator items of entrepreneurial skills variable has an average answer value of 121.57 and 116.09 , which mean the average value of the experiment class answers is higher than the control class.

\section{Descriptive Experimental Class Learning Outcomes (Y2)}

The respondents' assessment of student learning outcomes in the experimental class is presented in the table 6 .

Table 6 Descriptive Analysis of Experimental Class Learning Outcomes

\begin{tabular}{lc}
\hline \multicolumn{1}{c}{ Statistics } & Learning Outcomes \\
\hline Total respondents & 35 \\
Mean & 84.31 \\
Variance & 16,339 \\
Highest Value & 95 \\
Lowest Value & 80 \\
Standard Deviation & 4,042 \\
\hline
\end{tabular}

According to table 6, the results of descriptive analysis of the respondent's assessment data on entrepreneurial skills in the experimental class, it can be noted that it has an average answer value of 84.31 , which means very high. Following these results, it can be concluded that the students' learning outcomes of entrepreneurship learning in the experimental class have improved than before.

\section{Descriptive Control Class Learning Outcomes (Y2)}

The respondents' assessment of student learning outcomes in the control class is presented in table 7.

Table 7 Descriptive Analysis of Control Class Learning Outcomes

\begin{tabular}{lc}
\hline \multicolumn{1}{c}{ Statistics } & Learning outcomes \\
\hline Total respondents & 35 \\
Mean & 79.74 \\
Variance & 14.844 \\
Highest Value & 95 \\
Lowest Value & 75 \\
Standard Deviation & 3.853 \\
\hline
\end{tabular}

Source: Authors (2018).

According to table 7, the results of a descriptive analysis of the respondent's assessment data on the learning outcomes of control class students can be noted that it has an average answer value of 79.74, which means high. Following the 
results, it can be concluded that the students' learning outcomes of entrepreneurship learning in the control class have been improved than before.

\section{Recapitulation Results of Descriptive Analysis of Learning Outcomes of Experimental Classes with Control Classes}

Comparative assessment of respondents based on each indicator of learning outcome variable in the experimental class and the control class is presented in the table below:

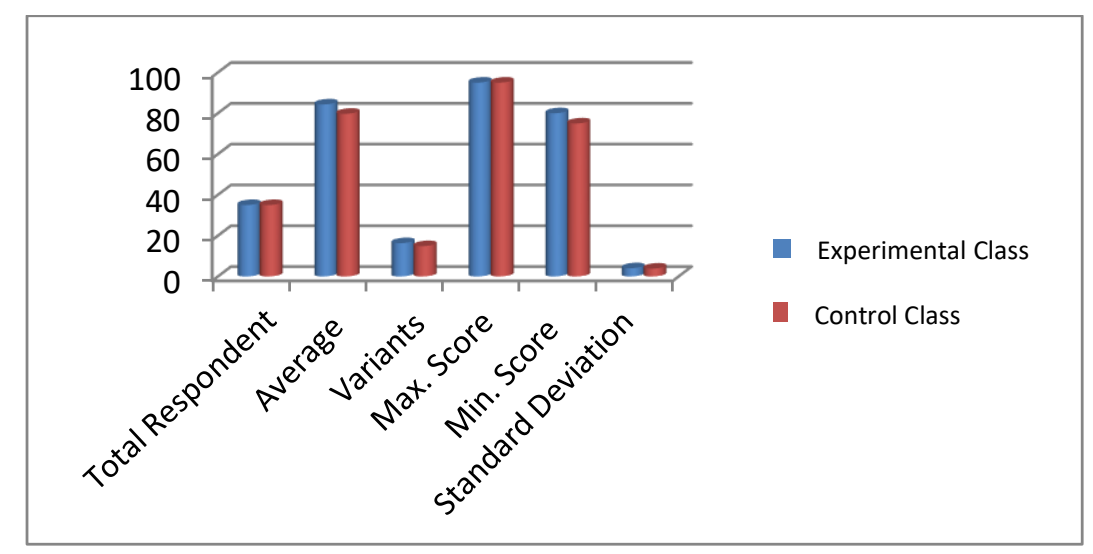

Figure 2 Recapitulation Results of Experimental Class Learning Outcomes Data with Control Classes

Based on Figure 2, from the descriptive analysis of respondent's assessment data on the learning outcomes of the experimental class and the control class, it can be noted that for the entire indicator items of learning outcomes have an average answer value of 84.31 and 79.74, respectively which means that the average value of the experimental class is higher than the control class.

\section{Analysis Result of Independent Samples Test for Entrepreneurial Skills Data} (Y1)

The study was conducted to analyze the effectiveness of role-playing learning models to improve students' entrepreneurial skills. The following analysis results of Independent Samples Test can be seen in Table 8: 
Table 8 Analysis Result of Independent Samples Test for Entrepreneurial Skills (Y1)

Independent Samples Test

\begin{tabular}{|c|c|c|c|c|c|c|c|c|c|}
\hline & \multicolumn{2}{|c|}{$\begin{array}{l}\text { Levene's Test } \\
\text { for Equality } \\
\text { of Variances }\end{array}$} & \multicolumn{7}{|c|}{ t-test for Equality of Means } \\
\hline & $\mathrm{F}$ & Sig & $\begin{array}{c}t_{\text {hitun }} \\
\mathrm{g}\end{array}$ & $t_{\text {tabel }}$ & $\mathrm{df}$ & $\begin{array}{l}\text { Sig. } \\
(2- \\
\text { tailed } \\
\text { ) }\end{array}$ & $\begin{array}{c}\text { Mean } \\
\text { Differe } \\
\text { nce }\end{array}$ & $\begin{array}{c}\text { Std. } \\
\text { Error } \\
\text { Differe } \\
\text { nce }\end{array}$ & $\begin{array}{c}95 \% \\
\text { Confidence } \\
\text { Interval of } \\
\text { the } \\
\text { Difference } \\
\end{array}$ \\
\hline & & & & & & & & & $\begin{array}{l}\text { Lowe Upper } \\
\mathrm{r}\end{array}$ \\
\hline $\begin{array}{l}\text { Equal } \\
\text { variances } \\
\text { assumed }\end{array}$ & ,831 & $\begin{array}{c}, 36 \\
5\end{array}$ & $\begin{array}{c}3,41 \\
9\end{array}$ & $\begin{array}{c}2.00 \\
0\end{array}$ & 68 & ,001 & 5,486 & 1,604 & $2,284 \quad 8,687$ \\
\hline $\begin{array}{l}\text { Equal } \\
\text { variances } \\
\text { not assumed }\end{array}$ & & & $\begin{array}{c}3,41 \\
9\end{array}$ & & $\begin{array}{c}67,55 \\
1\end{array}$ & ,001 & 5,486 & 1,604 & $2,284 \quad 8,688$ \\
\hline
\end{tabular}

According to table 8, it can be seen in testing the values for the comparison between the experimental class and the control class obtained by the thitung value and the significance values are 3.419 and 0.001 . These results indicate that the value of the thitung is greater than the value of $t_{\text {tabel }}(3.419>2.00)$ and the significance value is less than Alpha $5 \%(0.000<0.001)$ then the $\mathrm{H}_{0}$ hypothesis is rejected and it can be said that the result of role-playing learning is more effective than group guidancebased learning to improve students' entrepreneurial skills.

\section{Analysis of Independent Samples Test Learning Outcomes (Y2)}

In table 9 The results of Independent Samples Test are calculated: 
Independent Samples Test

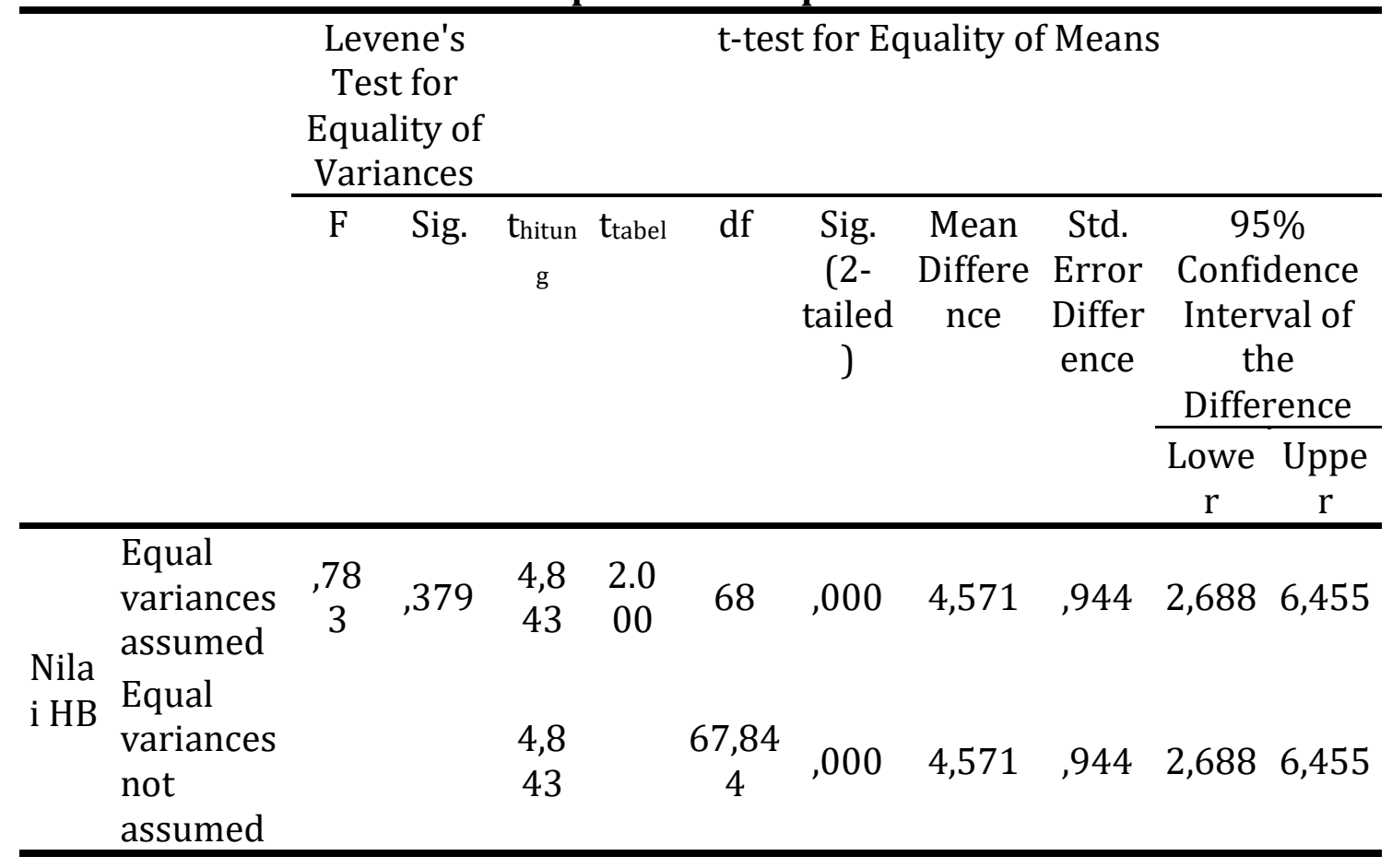

According to table 9, it can be seen in testing the values for the comparison between the experimental class and the control class obtained by the thitung value and the significance values are 4.843 and 0.000 . These results indicate that the value of the thitung is greater than the value of $t_{\text {tabel }}(4.843>2.00)$ and the significance value is less than Alpha $5 \%(0.000<0.000)$ then the $\mathrm{H}_{0}$ hypothesis is rejected and it can be said that the result of role-playing learning is more effective than guidance-based learning in entrepreneurial learning.

\section{Discussion}

Based on the analysis results of the Independent Samples Test data shows that role-playing learning results are more effective than group guidance-based learning to improve student entrepreneurial skills. The results of this study indicate that in the use of role-playing models, students can directly to play something that will be discussed in the learning process through their skills and give the impression of strong and durable in students' memory, besides giving pleasant experience, this model also gives the knowledge inherent in memory as well as having the opportunity to foster their ability to cooperate. The results of this study are supported by Kesten (2011) whose finding showed role-playing might have a place in teaching communication skills in the nursing school and can provide more effective learning in relationship between communication and the results learned. While the results of research conducted by Marsianus et al., (2014) found that roleplaying can improve students' speaking skills to express asking questions and to give opinions, by applying role-playing techniques in asking and giving opinions, students play their characters using prepared scripts. In addition, the students reflected that role-playing activities can improve their speaking skills. 
The results of role-playing learning are more effective than group guidancebased learning in entrepreneurial learning. The results of this research show that the role-playing learning model can increase the student's interest in the subject matter presented so that the learning objectives are easier to achieve. As well as from the learning experience that students have gained from these models can develop the ability to cooperate, communicate, and interpret an event. Through role-playing learning, students try to explore the relationships between people by demonstrating and discussing them, so that together students can explore their feelings, attitudes, values and various problem-solving strategies that might have an impact on improving learning outcomes. The result of this study in line with Tompkins' (1998) study which stated that role-playing is a very valuable model for learning, this is because it encourages thinking and creativity, allowing students to develop their skills and students' involvement in learning activities that occur.

\section{CONCLUSION}

Based on data analysis results it can be concluded that the results of roleplaying learning are more effective than group guidance-based learning to improve students' entrepreneurial skills. This model is more effective because students can practice directly playing something that will be discussed in the learning process through their skills and give a strong impression in student memory. Role-playing learning outcomes are also more effective than group guidance-based learning. This is as a positive impact of the student's interest in the subject matter presented by involving them directly with the roles that they play. It is recommended that entrepreneurial learning carried out not only the basis of theory but also required the students to portray directly as their entrepreneurial spirit through the development of other innovative learning models.

\section{REFERENCES}

Astuti, P. P., 2013. Efektivitas Metode Bermain Peran (Role Playing) Untuk Meningkatkan Keterampilan Komunikasi Pada Anak. Jurnal EMPATHY, Vol. 2 No. 1 Juli 2013.

Arikunto, S., 2006. Prosedur Penelitian Suatu Pendekatan Praktik.Jakarta: Rineka Cipta.

Azwar, S., 2003. Penyusunan Skala Psikologi. Yogyakarta: Pustaka Pelajar.

Bender, T., 2005. Role playing in online education: A teaching tool to enhance student engagement and sustained learning. Journal of Online Education.Volume 1, Number 4, April 2005 ISSN 1552-3233.

Cai, L., Peng, X., \& Wang, L., 2018. The characteristics and influencing factors of entrepreneurial behaviour: The case of new state-owned firms in the new energy automobile industry in an emerging economy. Technological Forecasting and Social Change 135, 112-120. https://doi.org/10.1016/j.techfore.2018.04.014

Chang, J., \& Alison, R., 2013. Assessing Students' Entrepreneurial Skills Development in Live Project. Journal of Small Business and Enterprise Development Vol. 20 No. 1. pp. 36-49. 
Christina, W., Purwoko, H., \& Kusumowidagdo, A., 2015. The Role of Entrepreneur in Residence towards the Students' Entrepreneurial Performance: A Study of Entrepreneurship Learning Process at Ciputra University, Indonesia. Procedia - Social and Behavioral Sciences 211, 972-976. https://doi.org/10.1016/j.sbspro.2015.11.129

Cosenz, F., \& Noto, G., 2018. Fostering entrepreneurial learning processes through Dynamic Start-up business model simulators. The International Journal of Management $\quad$ Education 16, 468-482. https://doi.org/10.1016/j.ijme.2018.08.003

Din, B.H., Anuar, A.R., \& Usman, M., 2016. The Effectiveness of the Entrepreneurship Education Program in Upgrading Entrepreneurial Skills among Public University Students. Procedia - Social and Behavioral Sciences 224, 117-123. https://doi.org/10.1016/j.sbspro.2016.05.413

Dyson, S.B., Chang, Y.-L., Chen, H.-C., Hsiung, H.-Y., Tseng, C.-C., \& Chang, J.-H., 2016. The effect of tabletop role-playing games on the creative potential and emotional creativity of Taiwanese college students. Thinking Skills and Creativity 19, 88-96. https://doi.org/10.1016/j.tsc.2015.10.004

Fitriati, R., \& Tuti, H., 2010. Entrepreneurial Skills and Characteristics Analysis on the Graduates of the Department of Administrative Sciences. Journal of Administrative Science and organization Fisip Universitas Indonesia.Vol. 17.No. 3.pp.262-275.

Jones, G., \& Pitelis, C., 2015. Entrepreneurial Imagination and a Demand and Supplyside Perspective on the MNE and Cross-border Organization. Journal of International Management 21, 309-321. https://doi.org/10.1016/j.intman.2015.07.003

Kesten, S. K., 2011. Role-Play Using SBAR Technique to Improve Observed Communication Skills in Senior Nursing Students. Journal of Nursing Education.2011;50(2):79-87

Marsianus, R, A., \& Dwi, R., 2014. Improving Students Speaking Skills To Express Asking And Giving Opinions Through Role Play. Jurnal Pendidikan dan Pembelajaran.Vol. 3 No. 3.

Peraturan Presiden Nomor 6 Tahun 2009 tentang Ekonomi Kretif.

Riduwan., 2007. Dasar-Dasar Statistika. Bandung: Alfabeta.

Santoso, R. B. E., 2011. Model Pembelajaran Role Playing. [online]. Tersedia: http://www.ras-eko.com/2011/05/model -pembelajaran-role-playing.html. diakes tanggal: 9 Oktober 2013.

Siska, Y., 2011. Penerapan Metode Bermain Peran (Role Playing) Dalam Meningkatkan Keterampilan Sosial Dan Keterampilan Komunikasi Anak Usia Dini. Jurnal Edisi Khusus No.2: 31-37.

Suprapto, T., 2009. Pengantar Teori \& Manajemen Komunikasi, Jakarta: Medpress.

Tompkins, K. Patricia, 1998. Role Playing/Simulation. The Internet TESL Journal, Vol. IV, No. 8, August 1998. From : http://iteslj.org/.

Usman, H., 2009. Manajemen: Teori, Praktek, dan Riset Pendidikan. Jakarta: Bumi Aksara. 